\title{
Hermeneutische Ethik nach Wittgenstein und die Literatur
}

\author{
Andreas Hunziker
}

\section{Hermeneutische Ethik nach Wittgenstein ...}

Seit knapp einem Jahr treffen wir uns ein paar Mal pro Semester am Freitagnachmittag in einem kleinen Arbeitskreis mit dem programmatischen Titel Hermeneutische Ethik nach Wittgenstein. Wie gesagt, es ist ein kleiner Kreis, aber immerhin gehört ihm auch Pierre Bühler an. In einer Kooperation des Instituts für Hermeneutik und Religionsphilosophie mit dem Institut für Sozialethik suchen wir im Anschluss an die hermeneutische Sprachphänomenologie Ludwig Wittgensteins (1889-1951) nach einer Alternative zur gegenwärtig dominierenden Denkweise innerhalb der angewandten Ethik.

Statt sich von der Frage leiten zu lassen, wozu wir moralisch verpflichtet sind, d.h. welche Handlungen wir mit solchen Gründen als verboten oder geboten ausweisen, die jedem einleuchten, setzt eine hermeneutische Ethik anders an. Sie versucht zu verstehen, was die Tradition unseren «moral sense` nannte: Jenes hochdifferenzierte und kulturell gewachsene 〈Organ〉 für die Bedeutung von Situationen und Handlungen. Woher kommt es, wie ist es zu verstehen, dass mir etwas an dieser kranken Taube liegt, welche jene Jungen durch die Gasse unseres Städtchens jagen, um sie schliesslich mit Steinen zu bewerfen? Soll ich es ‘Würde〉 nennen oder ‘Geschöpflichkeit〉 und wie hängt es mit anderen meiner Einstellungen, Reaktionsweisen und Überzeugungen zusammen? Wie verleihe ich dem Ausdruck, was mich an dieser Handlungsweise abstösst? Worin besteht jener «moralische Sinn', den die Jungen in dieser Situation verloren zu haben scheinen und weswegen ihre Handlungen mir als 〈gefühllos〉 und 〈brutal erscheinen?

Eine hermeneutisch ausgerichtete Ethik artikuliert, welche Bedeutung etwas für mich oder uns hat oder haben könnte. Sie versucht die Phänomene in ihrer Komplexität zu erkunden, ohne sie vorschnell mit ethischen Theorien (und entsprechend dürrem Vokabular) zuzudecken. Und gerade das macht diese hermeneutische Denkweise auch interessant für die Theologie: Hermeneutisches Denken sucht keinen weltanschaulich neutralen, unpersönlichen 
Zugang zu den Phänomenen, sondern ist auch offen für die spezifischen Sinndimensionen, welche sich Menschen eröffnen, die ihre Fremd-, Welt- und Selbstverhältnisse vor Gott zu gestalten versuchen.

\section{... und die Literatur}

Als ein herausragendes Beispiel für eine solche hermeneutisch-ethische Denkweise haben wir uns im ersten Semester mit dem moralphilosophischen Denkansatz der amerikanischen Philosophin Cora Diamond auseinandergesetzt. Charakteristisch für ihren Umgang mit moralischen Fragen ist nicht zuletzt die wesentliche Rolle, welche der Einbezug von literarischen Beispielen dabei spielt. Ich konzentriere mich auf eine Stelle, in der Diamond auf eine Passage in Fjodor Dostojewskijs Die Brüder Karamasow Bezug nimmt.

Diese Stelle findet sich in dem Text «Wittgenstein and Metaphysics» ${ }^{1}$, in welchem Diamond Wittgensteins spätere Metaphysikkritik als Kritik an einer metaphysischen Denkweise interpretiert. Sie unterscheidet dabei zwischen «dem metaphysischen Geist) und dem, was sie «den realistischen Geist` nennt:

«The laying down of philosophical requirements, the characteristic activity of the metaphysical spirit, may be contrasted with looking at the use, looking at what we do. Thus, for example, there is on the one hand what we might lay down, in some philosophical theory, as essential to rule-following, to something's being in accordance with a rule; in contrast there is description of the face, the physiognomy, of what we call «obeying a rule» in everyday life, of all that belongs to that face. The philosophical theory lays down, without looking, what must be present in following a rule, while Wittgenstein's talk of what is possible is entirely different. Imagine such-and-such a change, he will say; and with the face of the activity thus altered, do you still want to call this following a rule? The important thing then is not what answer you give, but your willingness to look, i.e., your not laying down general philosophical conditions.»²

Im metaphysischen Geist drückt sich unser Wunsch nach philosophischen Erklärungen und Theorien aus. Wir fragen nach den

C. Diamond, Wittgenstein and Metaphysics, in: Dies., The Realistic Spirit. Wittgenstein, Philosophy, and the Mind, Cambridge/Mass. u.a. ${ }^{4} 2001$, 13-38. Dieser Text ist der eine von zwei Einleitungstexten in den Aufsatzband.

2 Ebd., 21. 
notwendigen und allgemeinen Bedingungen, nach dem, was der Fall sein muss, damit etwas möglich ist: Welche Bedingungen müssen erfüllt sein, damit wir einer Regel folgen können, damit wir auf etwas referieren können, damit wir ein Wort wie 〈Schmerz〉 oder 〈Mitleid meinen bzw. verstehen können? Fragen wir auf diese Weise, dann sind oder werden die Einzelheiten dessen, was wir sagen und tun für unser philosophisches Verstehen nebensächlich. Wir werden in philosophisch irreführende Abstraktionen hineingeführt (welche wir dann wiederum durch entsprechende Theorien zu kompensieren versuchen). So geht mit dem metaphysischen Geist derVerlust dessen einher, was umgekehrt gerade den realistischen Geist auszeichnet:Das Hinschauen und die Beschreibung der Physiognomie dessen, worin das Folgen einer Regel, das Referieren auf ein Phänomen dort oder dort im Kontext unseres alltäglichen Lebens besteht. Der realistische Geist schaut, er schaut hin, wie das Wort 〈Schmerz〉 oder 〈Mitleid〉 mit unserem übrigen Leben verbunden ist, welchen ganz besonderen Ort es in den Mustern des Lebens und Redens, den Reaktionen, Handlungen, Worten, Gedanken, Interessen und Gefühlen von uns Menschen hat.

In welchem Verhältnis aber steht dieser (realistische Geist) (und dessen kritische Rückseite: die Kritik am «metaphysischen Geist`) zu Diamonds ethischer Denkweise?

«In the papers on ethics, I am concerned with our philosophical ideas about what the role of universality and universal principles must be in moral thought and discussion; also, with a view (which we may take to be essential in moral thought) of the self, of what we as moral agents must be taken to share; and also with what concepts can be morally relevant. The papers are, then, all attempts to think about ethics in a realistic spirit, i.e., not in the thrall of metaphysical requirements. They make two sorts of claims about the effects of such thralldom. The requirements which we lay down stop us seeing what moral thought is like; further, they lead us to construct stupid or insensitive arguments, arguments which are capable of hiding our own genuine ethical insights from ourselves and of giving others good grounds for identifying philosophical argument in ethics with sophistry.» ${ }^{3}$

Der metaphysische Geist schlägt sich in einer Denkweise nieder, die anstatt hinzuschauen, worin das moralische Denken in unserem Leben (unseren Reaktionen, Handlungen, Worten, Gedanken, Interessen und Gefühlen) besteht, philosophische Bedingungen da-

3 Ebd., 22f. 
rüber aufstellt, worin die ethische Rationalität bestehen muss. In der Tat gehört es zum ethischen Denken, dass gewisse Überlegungen als irrelevant, als voreingenommen oder als falsch beurteilt werden. Aber es ist etwas anderes, wenn wir solche zu unserem moralischen Leben gehörenden Unterscheidungen gleichsam in eine Mythologie dieser Unterscheidungen verwandeln: Wir lassen uns dann von einem Ideal faszinieren, einem Ideal ethischer Rationalität, das allen ethischen Argumenten zugrunde liegen muss, wenn immer diese Argumente mehr als blosse Appelle an unsere subjektiven Gefühle oderVorurteile sind. ${ }^{4}$ Es sind Ideale dieser Art, die uns blind machen, die uns unseren Sinn dafür verlieren lassen, worin die Eigenart moralischen Handelns, Empfindens und Denkens in unserem Leben besteht. An die Stelle unseres «moralischen Sinnes` dafür, was in unserem Leben moralisch von Gewicht ist, treten dann philosophische Theorien, welche die Stärke der ethischen Argumente an dem messen, was ihr das Ideal ethischer Rationalität vorschreibt.

Als Beispiel für diese metaphysische Denkweise führt Diamond folgendes Argument von Peter Singer an:

«We have seen that the experimenter reveals a bias in favor of his own species whenever he carries out an experiment on a non-human for a purpose that he would not think justified him in using a human being, even a retarded human being. $\|^{5}$

Das 〈Stupide〉 und 〈Unsensible〉 von Singers Argumentationsweise zeigt sich bereits in seinem Gebrauch des Wortes «even». Singers Argumentation ist von der Idee geleitet, dass das Experimentieren mit behinderten Menschen einfacher $\mathrm{zu}$ rechtfertigen ist als das Experimentieren mit «normalen` Menschen. Er geht davon aus, dass wenn ein Wissenschaftler seine Präferenz fürTierversuche gegenüber Experimenten mit Menschen begründen kann, er dies mit Berufung auf etwas tun muss, das wir Menschen (mehr) haben und was die Tiere nicht (bzw. weniger) haben, nämlich intellektuelle Fähigkeiten. Weil nun aber behinderte Menschen diese Fähigkeiten nicht (bzw. in einem geringeren Ausmass) haben als «normale Menschen, wird die Rechtfertigung der Präferenz von Experimenten mit Tieren gegenüber solchen mit Menschen zur Rechtfertigung der Präferenz von Experimenten mit behinderten Menschen gegenüber solchen mit «normalen` Menschen. Folgt man der Logik dieser Argumentation nicht, wird man des Spezieismus bezichtigt.

\footnotetext{
4 Vgl. C. Diamond, Philosophy and the Mind, in: Diamond, The Realistic Spirit, s. Anm. 1, 8f.

5 P. Singer, Animal Liberation, 1975, 82.
} 
Diamond kontrastiert diese verbreitete ethisch-metaphysische Denkweise mit einer Passage aus Die Brüder Karamosov. Für sie drückt sich in diesem Stück Literatur genau jener Sinn für die Wirklichkeit des Moralischen aus, für den Singers Denkweise blind ist und blind macht. Ihre Zuwendung zur Literatur bedeutet keine Verabschiedung von der Philosophie, sondern das Plädoyer für einen Wechsel der Perspektive und der Methode der (Moral-)Philosophie die Aufmerksamkeit für das, was wir in unserem alltäglichen Leben sagen und tun bzw. sagen und tun könnten (für das also, was für eine an den Idealen ethischer Rationalität ausgerichtete Denkweise in der Regel nicht von Bedeutung sein kann):

\begin{abstract}
«Putting these points another way: in The Brothers Karamazov, the evil heart of a central character is revealed by what he does to the village idiot, a girl cared for by others in the village, who lacks even the capacity any normal animal has to look after itself; severyone in the village was willing to look after her as being an idiot, and so specially dear to God.) Any competent reader of Dostoyevsky must draw on an understanding of Karamazov's act as specially vile in its abuse of the specially vulnerable girl; but that understanding is not something a competent reader of moral philosophy is expected to be able to draw on. It is thus possible for moral philosophy to contain arguments like the one I have sketched, remarks like the one I have quoted, which will seem (to those drawing on the capacity for moral thought and understanding expected by Dostoyevsky) to evince utter blindness to what common humanity recognizes. One reason, then, why a theme of the papers on ethics is the relation between moral philosophy and literature is that literature shows us forms of thinking about life and what is good and bad in it, forms of thinking which philosophical requirements on the character of thought, mind, and world may lead us to ignore. $\aleph^{6}$
\end{abstract}

Das Mädchen, um das es in dieser Passage geht, ist Lisaweta Smerdjastschaja, «die Stinkende), ein kleinwüchsiges Wesen mit einem Gesicht, das "völlig idiotisch» war. ${ }^{7}$ Während ihres ganzen Lebens, im Sommer wie im Winter, war sie barfuss und «nur mit einem groben Leinenhemd gekleidet». Ihr grosser Haarschopf war schmutzig und verklebt, «voll von Erde, Blättern, Holzspänen und Holzwolle, denn sie nächtigte immer auf der Erde und im Schlamm.»

${ }_{6}$ Diamond, Wittgenstein and Metaphysics, s. Anm. 1, $23 \mathrm{f}$.

7 Ich beziehe mich in diesem Abschnitt auf F. Dostojewskij, Die Brüder Karamasow. Neu übersetzt von S. Geier, Frankfurt a.M. 2008, 155-161. 
Sprechen konnte sie nicht, «bewegte nur hin und wieder die Zunge und muhte». Ihre Mutter war früh gestorben, ihr Vater war ein verarmter Säufer, der Lisaweta unmenschlich verprügelte, wenn sie nach Hause kam. Alle anderen im Dorf schienen sie aber zu mögen, und viele versuchten sie, soweit sie es zuliess, zu unterstützen - und zwar gerade weil sie eine solche 〈Idiotin〉 war! Und gerade weil sie ein solch verletzlich-stummes Geschöpf war, reagierte «die ganze Stadt mit aufrichtiger und außerordentlicher Empörung», als sich das Gerücht verbreitete, dass sich Fjodor Pawlowitsch Karamasow - der moralisch verkommene, bösartige Vater der drei Brüder Karamasow - nach einer seiner nächtlichen Orgien an ihr vergangen habe.

Natürlich muss es jede Leserin und jeder Leser an sich selbst ausprobieren. Aber wer von uns, der das so irritierende wie berührende Kapitel «Lisaweta Smerdjastschaja» in Die Brüder Karamosov liest, würde den Missbrauch an Lisaweta nicht als in gewisser Hinsicht besonders abstossend wahrnehmen - und zwar gerade weil dieses Mädchen sein menschliches Leben in einer solch tumben Form zu führen hat? Für denjenigen jedenfalls, der die besondere Bösartigkeit dieses Verbrechens sieht, für den erscheint Singers Argumentationsweise zumindest in dieser Allgemeinheit - seltsam realitätsfern, also seltsam weit von dem entfernt, was es für uns bedeutet oder bedeuten könnte, mit der 〈Wirklichkeit des Moralischen〉 konfrontiert zu sein: Nicht obwohl, sondern gerade weil sie diese verletztliche Idiotin ist, sehen sie die Bewohner des Dorfes als ein vor Gott besonders kostbares Geschöpf. ${ }^{8}$ Für Diamond ist dies nicht nur ein weiteres Beispiel für den Kontrast zwischen dem metaphysischen und dem realistischem Geist und dem Sinn von letzterem dafür, was es heisst, ein moralisches Leben zu führen. Es ist für sie auch ein charakteristisches Beispiel für die Beziehung zwischen der Moralphilosophie und der Literatur. Die Literatur macht uns auf Weisen aufmerksam, über das Leben und was in ihm gut und böse ist, nachzudenken, welche die philosophischen Bedingungen für ein gutes moralisches Argument gerade ignorieren. $\mathrm{Zu}$ diesen anderen Denkformen gehört nicht zuletzt das Erzählen und Lesen von Geschichten (in einem sehr weiten Sinne) - und zwar nicht nur als Illustration, sondern als eine eigene Weise der Argumentation.

- Dr. Andreas Hunziker ist geschäftsführender Oberassistent des Instituts für Hermeneutik und Religionsphilosophie an der Universität Zürich.

\footnotetext{
8 Ich konnte Diamonds <everyone in the village was willing to look after her as being an idiot, and so specially dear to God in meiner deutschen Übersetzung der Brüder Karamsow (s. Anm. 7) nicht verifizieren - auf jeden Fall scheint mir diese Formulierung aber präzise den Sinn des 〈Lisaweta-Kapitels» zu erfassen.
} 